\title{
Research Progress on Flat Epithelium of the Inner Ear
}

\author{
Lu HE ${ }^{1}$, Jing-Ying GUO ${ }^{1}$, Ke LIU ${ }^{1}$, Guo-Peng WANG ${ }^{1}$, Shu-Sheng GONG ${ }^{1}$ \\ ${ }^{1}$ Department of Otolaryngology-Head and Neck Surgery, Beijing Friendship Hospital, Capital \\ Medical University, Beijing, China
}

Received February 3, 2020

Accepted June 9, 2020

Epub Ahead of Print September 9, 2020

\section{Summary}

Sensorineural hearing loss and vertigo, resulting from lesions in the sensory epithelium of the inner ear, have a high incidence worldwide. The sensory epithelium of the inner ear may exhibit extreme degeneration and is transformed to flat epithelium (FE) in humans and mice with profound sensorineural hearing loss and/or vertigo. Various factors, including ototoxic drugs, noise exposure, aging, and genetic defects, can induce FE. Both hair cells and supporting cells are severely damaged in $\mathrm{FE}$, and the normal cytoarchitecture of the sensory epithelium is replaced by a monolayer of very thin, flat cells of irregular contour. The pathophysiologic mechanism of FE is unclear but involves robust cell division. The cellular origin of flat cells in FE is heterogeneous; they may be transformed from supporting cells that have lost some features of supporting cells (dedifferentiation) or may have migrated from the flanking region. The epithelial-mesenchymal transition may play an important role in this process. The treatment of FE is challenging given the severe degeneration and loss of both hair cells and supporting cells. Cochlear implant or vestibular prosthesis implantation, gene therapy, and stem cell therapy show promise for the treatment of $\mathrm{FE}$, although many challenges remain to be overcome.

\section{Key words}

Wounds and injuries - Flat epithelium - Cochlear • Vestibular • Hair cell • Supporting cell

\section{Corresponding authors}

G.-P. Wang and S.-S. Gong, Department of Otolaryngology-Head and Neck Surgery, Beijing Friendship Hospital, Capital Medical University, Beijing 100050, China. E-mail: guopengent@163.com (Guo-Peng Wang), gongss1962@163.com (Shu-Sheng Gong)

\section{Introduction}

The sensory epithelia of the mammalian inner ear in the cochlea, utricle, saccule, and crista ampullaris are important for hearing and balance perception. Each of these sensory end-organs consists of mechanotransducing hair cells (HCs), surrounding supporting cells (SCs), and neural endings that innervate to HCs. Different insults result in varying degrees of damage to the sensory epithelium of the inner ear. In most cases, HCs are damaged but SCs remain unaffected and expand to fill the space formerly occupied by the HCs (Leonova and Raphael 1997, Wang et al. 2010). In other cases, both HCs and SCs are damaged, resulting in extreme degeneration of the sensory epithelium, which is replaced by a layer of flat cells of irregular contour. This pathologic change occurs in the cochlear and vestibular end-organs of animal models and is referred to as flat epithelium (FE) (Jahan et al. 2018, Raphael et al. 2007, Wang et al. 2017). FE has also been found in temporal bone specimens of patients with severe deafness or intractable Meniere's disease (McCall et al. 2009, Nadol and Eddington 2006, Teufert et al. 2006), indicating that FE is an important pathological change in patients with diseases of the inner ear. However, the pathological features and pathogenesis of FE are unclear and inducing $\mathrm{HC}$ regeneration in $\mathrm{FE}$ to recover hearing or vestibular function is problematic. Herein we review the etiology, characteristics, mechanisms, and intervention strategies for FE of the mammalian inner ear. 


\section{Etiology}

\section{Genetic factors}

Histopathological studies of human temporal bone show hereditary factors result in various degrees of change in the organ of Corti (Bommakanti et al. 2019). Severe degeneration of the organ of Corti occurs in patients with nonsyndromic or syndromic profound hearing loss. In patients with DFNA5 mutation, the organ of Corti is reduced to an FE in the basal and middle turns of the cochlea, which is accompanied by severe atrophy of the cells of the stria vascularis and spiral ganglion (Nadol et al. 2015). Mutations in GJB2, which encodes connexin 26 (Cx26), are the most common cause of nonsyndromic hereditary deafness. In a mouse model of GJB2 mutation, HCs and differentiated SCs degenerate in the cochlea, resulting in FE (Sun et al. 2009, Takada et al. 2014). Although there is no evidence that GJB2 mutations lead to inner ear FE in human, agenesis of $\mathrm{HCs}$ has been observed in human temporal bones with GJB2 mutations (Jun et al. 2000). FE is also found in patients with syndromic hereditary deafness conditions, such as Usher syndrome. Of the three types of Usher syndrome, type 1 presents the most serious hearing loss and vestibular dysfunction, and patients with this type exhibit severe degeneration of the organ of Corti with total loss of HCs and SCs (Nadol and Eddington 2006, Wagenaar et al. 2000). The Pcdh15 mutation is associated with Usher syndrome type 1 , and the sensory epithelium of the cochlea is replaced by $\mathrm{FE}$ in Pcdh15 mutation mice (Pawlowski et al. 2006). Atonal homolog1 (Atoh1) is a crucial basic helix-loop-helix transcription factor for HC development and differentiation. Several studies have reported that Atoh1 knockout mice exhibit complete loss of differentiated HCs, and the organ of Corti and vestibular sensory epithelium are replaced by $\mathrm{FE}$ in the postnatal stage (Liu et al. 2016, Pan et al. 2012, Pan et al. 2011).

\section{Aminoglycoside antibiotics}

Aminoglycoside antibiotics are important for treating life-threatening bacterial infections, such as tuberculosis, endocarditis, and those of the respiratory and urinary tracts (Jiang et al. 2017). However, the ototoxicity of aminoglycoside antibiotics can significantly damage $\mathrm{HCs}$ and/or SCs, resulting in absence of the organ of Corti in humans (Kusunoki et al. 2004b). In animal models, FE can be induced by administration of high doses of aminoglycosides. In the cochlea of guinea pig, the organ of Corti is replaced by FE 4 days after application of neomycin (Kim and Raphael 2007), suggesting its rapid degeneration. Additionally, cochlear FE occurs when it is lesioned by aminoglycoside plus diuretics in cats and mice (Coco et al. 2007, Taylor et al. 2012). In the vestibular sensory epithelium, a high dose of streptomycin induces FE in the utricular sensory epithelium (He et al. 2020, Wang et al. 2017).

Noise

In the basilar papilla of chicken, exposure to noise $(1500 \mathrm{~Hz}, 120 \mathrm{~dB}, 24 \mathrm{~h}$ or $900 \mathrm{~Hz}, 120 \mathrm{~dB}, 48 \mathrm{~h}$ ) results in moderate damage, which is characterized by loss of HCs but survival and expansion of SCs. When the noise intensity is elevated to $123 \mathrm{~dB}$, both HCs and SCs are damaged, and the basilar papilla is replaced by FE (Cotanche et al. 1995). The cochlear sensory epithelium of guinea pig transforms into FE with no signs of differentiated HCs and SCs after two months of noise exposure to gunfire (Yang et al. 2012). Similarly, in chinchilla and mice, severe noise exposure leads to degeneration of the cochlear sensory epithelium, which is replaced by FE (Roberto and Zito 1988, Willott et al. 1994).

\section{Other factors}

Kusunoki et al. reported a significant correlation between loss of HCs and aging in the cochlea of temporal bone of aging humans, and the organ of Corti completely degenerated in some regions of the cochlea (Kusunoki et al. 2004a). Smittkamp et al. (2003) found that aging birds sustained total cochlear damage, and large regions were replaced by hyaline cells. Therefore, aging is a significant factor leading to FE (Yamoah et al. 2020). Additionally, inner ear infection may induce FE. Teufert et al. (2006) found total loss of the organ of Corti in patients with labyrinthitis-induced deafness. Moreover, a monolayer of epithelial cells is present in the vestibular end-organs of some patients with intractable Meniere's disease (McCall et al. 2009).

\section{Characteristics of $\mathrm{FE}$ of the inner ear}

\section{Morphological characteristics}

HCs and differentiated SCs disappear in FE, which consists of a thin layer of epithelial cells of variable size (Kim and Raphael 2007) with surface microvilli (Wang et al. 2017). The width of FE cells 
ranges from less than $20 \mu \mathrm{m}$ to greater than $40 \mu \mathrm{m}$, and the cell height is similar to that of its nucleus (Kim and Raphael 2007). Flat cells typically contain fewer organelles and larger nuclei than normal HCs and SCs. The tissue structure of FE may exhibit polarization and a radial morphology (Taylor et al. 2012).

\section{Biological characteristics}

Maintenance of intercellular junctions: Intercellular junctions are necessary for homeostasis of the lymphatic fluid of the inner ear. In the normal organ of Corti, the tight junction protein ZO-1 is located between inner hair cells, outer hair cells, and the surrounding SCs in the reticular lamina, and is an important component of the perilymph-endolymph barrier. The gap junction protein $\mathrm{Cx} 26$ is present in the basilar membrane and lateral wall of the cochlea and participates in perilymph-endolymph ion transport (Jagger and Forge 2014). ZO-1, Cx26, and Cx30 are present on the surface of FE cells (Kim and Raphael 2007, Taylor et al. 2012), indicating that FE maintains the integrity and the ion transport ability of the perilymph-endolymph barrier.

Metabolic activity and mitosis: Protein kinase C (PKC) plays important roles in cell cycle progression, cell differentiation, gene expression, and cytoskeletal remodeling (Isakov 2018). Ladrech et al. (2017) found that in the normal cochlea of rat, only inner HCs and some types of SCs expressed PKC, while all FE cells strongly expressed PKC, indicating that FE cells have high metabolic activity. The level of mitosis is high at the early stage of flattening (Kim and Raphael 2007). At 4 days after neomycin treatment in the cochlea of guinea pig, flat cells show robust proliferation; however, proliferation is absent at 7 days. The cell-cycle inhibitor $\mathrm{p} 27^{\mathrm{kip} 1}$ shows synchronous changes with the extent of mitosis (Kim and Raphael 2007). In moderate lesions, the proliferation rate of SCs is markedly lower than that in FE (Yamasoba and Kondo 2006). In vitro, proliferation is initiated by the loss of cell-cell contact, which is important for maintaining epithelial confluence in the inner ear (Meyers and Corwin 2007, Tamiya et al. 2010). Therefore, discontinuity of the lesioned epithelium caused by cell death may trigger cell division in FE of the inner ear.

Expression of markers of epithelial and mesenchymal cells: Using scanning electron microscopy, Ladrech et al. (2017) reported that during FE formation in the inner ear, epithelial cells of the outer spiral sulcus (tectal cells, Hensen cells, Claudius cells, and Boettcher cells) migrated to the medial side to cover the damaged organ of Corti. The expression of epithelial markers, such as E-cadherin and laminin, were decreased. These researchers hypothesized that these epithelial cells underwent the epithelial-mesenchymal transition (EMT) and subsequently acquired certain mesenchymal characteristics. The EMT increases cell differentiation, migration, and apoptosis (Nieto et al. 2016). In the nervous system, the EMT is not only involved in organ development and embryo formation but is also closely associated with wound healing, tissue regeneration, and organ fibrosis (Chen et al. 2015, Kalcheim 2015, Kuznetsova et al. 2014). Moreover, the EMT participates in the development of the inner ear (Johnen et al. 2012, Kobayashi et al. 2008, Simonneau et al. 2003) and the proliferation of inner-ear sensory-epithelium cells of adult vertebrates in vitro (Hu and Corwin 2007, Zhang and $\mathrm{Hu}$ 2012). Therefore, the loss of cell-cell contact due to severe lesions in the sensory epithelium of the inner ear induces the EMT and cell proliferation, which promote wound healing.

Gene expression profiles: Genes expressed prior to Atoh1 in undifferentiated sensory precursor cells, such as BDNF, Sox2, and Proxl, are still expressed in the undifferentiated cochlear sensory epithelium of Atoh1null mice (Dabdoub et al. 2008, Fritzsch et al. 2010, Fritzsch et al. 2005). Pan et al. reported that Fgflo, a gene expressed in the GER of developing cochlea, and Bmp4, a gene expressed in developing Hensen's and Claudius cells, were expressed in the undifferentiated organ of Corti (Pan et al. 2012, Pan et al. 2011). Wang et al. (2017) found that some vestibular FE cells expressed Sox2 after streptomycin-induced damage. Future studies are still needed to illuminate gene expression profiles of the inner ear FE.

Regeneration capacity: Nonmammalian vertebrates possess the ability to completely regenerate HCs in FE in the inner ear (Girod et al. 1989). Avian cochlear sensory epithelium exhibits mature-appearing HCs and SCs, and complete recovery from FE of the inner ear caused by exposure to loud noise (Girod et al. 1989). In contrast, neither spontaneous nor Atohl-induced HC regeneration occurs in $\mathrm{FE}$ of the mammalian cochlea (Izumikawa et al. 2008). In the mammalian vestibular FE, a small number of myosin VIIa-positive/Sox2-positive cells are present, and some exhibit surface immature hair bundles, indicating spontaneous regeneration of $\mathrm{HCs}$ (Wang et al. 2017). Atohl overexpression with the 
treatment of suberoylanilide hydroxamic acid (SAHA) promotes myosin VIIa expression in vestibular FE cells, suggesting the potential capacity of $\mathrm{HC}$ regeneration in vestibular FE (He et al. 2020).

\section{Innervation}

SCs protect unmyelinated fibers and express neurotrophic factors, which play an important role in the survival of spiral ganglion neurons (SGNs) and nerve fibers (Sugawara et al. 2005, Zilberstein et al. 2012). SGNs and nerve fibers degenerate secondary to the loss of HCs and SCs. Additionally, lesions induced by various factors, including noise, aminoglycosides, and aging, can directly damage nerve innervation in the inner ear (Kujawa and Liberman 2009, Makary et al. 2011, Raul et al. 2001). Nerve degeneration in FE of the inner ear in several animal species has been reported. Izumikawa et al. (2008) and Shibata et al. (2010) found that nerve fibers retracted in cochlear FE at 1 week after injury; the number of SGNs was significantly decreased, and the cell body of neurons shrank compared to the normal state. In the cochlea of Cx26-null mice, SGNs are almost completely lost, and the organ of Corti degenerates (Sun et al. 2009). In contrast, in vestibular FE of mice, nerve fibers and neurons show delayed degeneration after damage to HCs and SCs (Wang et al. 2017). In the $\mathrm{FE}$ of the human inner ear, neurodegeneration may occur over a long time after hearing loss. The number of SGNs is reduced in cochlear FE, but they do not completely disappear (Nadol and Eddington 2006, Nadol et al. 1989). In human vestibular $\mathrm{FE}$, the morphology of calyces and nerve fibers remain relatively normal several years after the onset of Meniere's disease (McCall et al. 2009). Nerve maintenance in human FE provides a therapeutic opportunity for functional recovery.

\section{Mechanisms of FE formation in the inner ear}

The inner ear of nonmammalian vertebrates undergoes self-repair after severe injury. At the early stage, hyaline or cuboidal cells proximate to the basilar papilla (where $\mathrm{HCs}$ and $\mathrm{SCs}$ are located), migrate into the damaged sensory epithelium to form FE, and subsequently divide and differentiate into mature $\mathrm{HCs}$ and SCs (Cotanche et al. 1995, Girod et al. 1989). Nevertheless, the mechanism of FE formation in the mammalian inner ear is unclear; two hypotheses have been proposed (Figs 1, 2). First, the original SCs (Dieter's cells, pillar cells, phalangeal cells or vestibular SCs) dedifferentiate following damage and subsequently form FE. Some cells in the vestibular FE exhibit characteristics of SCs, i.e. expression of the SC marker Sox 2 but not the HC marker myosin VIIa (Wang et al. 2017). Lineage tracing studies with $P l p-C r e E R^{T 2}: R o s a 26^{\text {tdTomato }}$ mice and GLAST$C_{\text {reER }}{ }^{T 2}:$ Rosa26 $6^{\text {tdTomato }}$ mice show that some vestibular FE cells express tdTomato (He et al. 2020). These studies suggest that FE cells may originate from SCs. However, the extent of damage to SCs required for FE formation is unclear. FE may be present in only some regions of the organ of Corti (Kim and Raphael 2007); alternatively, a small patch of FE may be interspersed with areas of scar formation (Taylor et al. 2012). Second, HCs and SCs die after being damaged, and cells surrounding the sensory epithelium migrate into the area occupied by HCs and SCs. Ladrech et al. (2017) found that cells on the lateral side of the organ of Corti, such as tectal cells and Hensen cells, migrated inwards and covered the scar structure. Taylor et al. (2012) reported that FE cells shared properties with the surrounding cells, e.g. high expression of $\mathrm{Cx} 26$ and $\mathrm{Cx} 30$; no expression of $\mathrm{Cx} 43$, acetylated tubulin or KCC4; and large gap junctions in the lateral walls. He et al. (2020) found that transitional epithelial cells might be a source of vestibular FE. Future studies on cellular-lineage tracing using specific Cre mouse lines to fate-map cell types in the inner ear would provide insight into the mechanism of FE formation.

\section{Intervention strategies for $\mathrm{FE}$ of the inner ear}

\section{Cochlear implantation and innervation protection}

Cochlear implantation is effective for profound sensorineural hearing loss (Naples and Ruckenstein 2020). Cochlear implantation bypasses the damaged sensory HCs and directly stimulates the SGNs. Thus, the outcome of cochlear implantation is dependent on the presence of sufficient neurons and nerve fibers in the cochlea. Because innervation of the inner ear is degenerated in FE (Nadol and Eddington 2006, Nadol et al. 1989, Wang et al. 2017), preservation of innervation following damage is vital for a satisfactory outcome of cochlear and vestibular implants (Perez et al. 2017). Following cochlear damage, overexpression of neurotrophins induces considerable regrowth of peripheral auditory fibers in the basilar membrane area and preserves SGNs. Therefore, induced overexpression of neurotrophins has potential for maintaining innervation or inducing nerve regeneration in FE (Budenz et al. 2015, Fukui and Raphael 2013, Shibata et al. 2011, Shibata et al. 2010, Wise et al. 2010). 
A
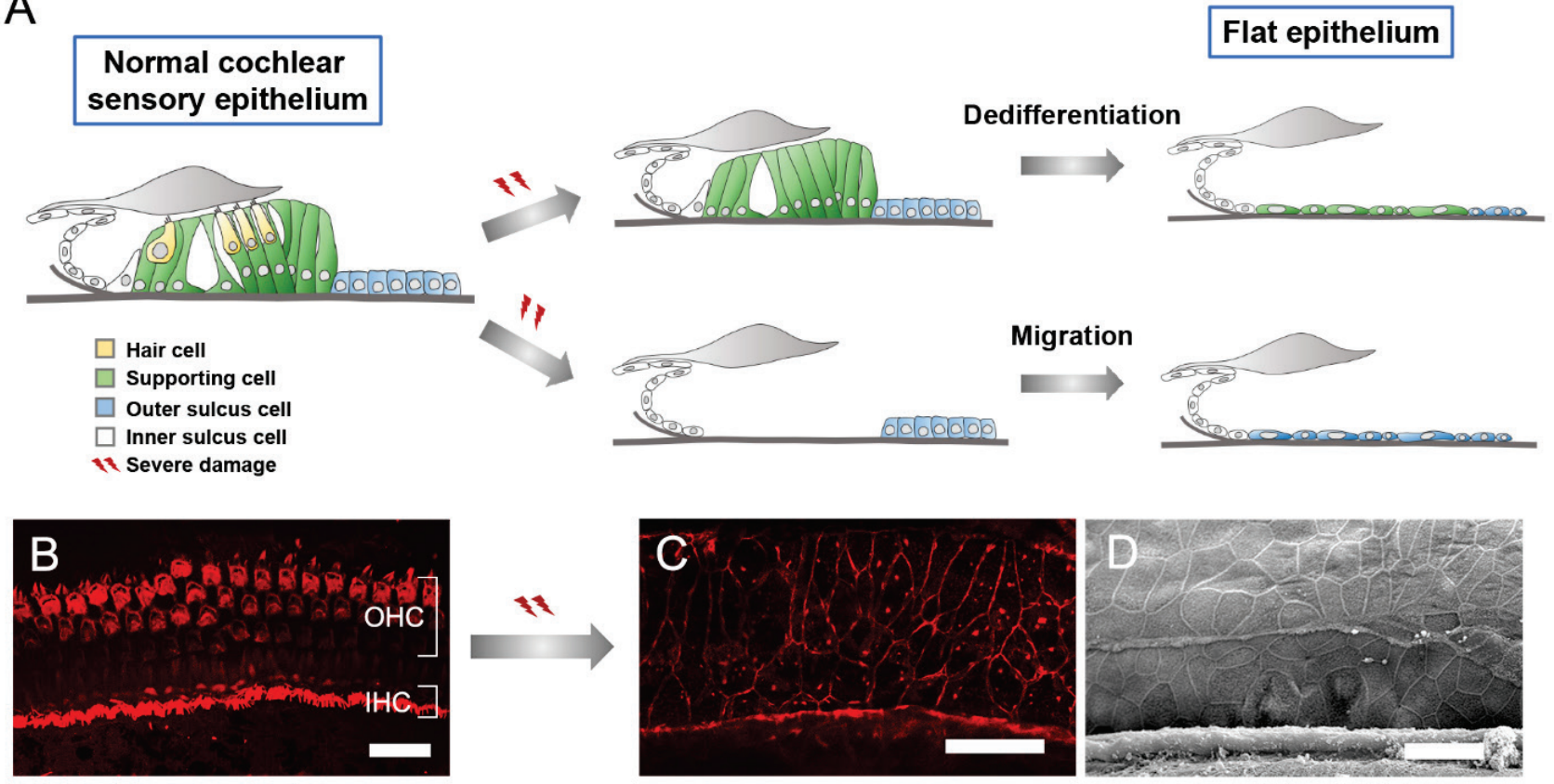

Fig. 1. Postulated mechanisms of formation of cochlear flat epithelium (FE) in mammals. (A) Schematic figures of cochlear FE formation. (B) Confocal image showing normal out hair cells (OHCs) and inner hair cells (IHCs) stained by phalloidin. (C) A confocal image of cochlear FE stained by phalloidin shows that normal OHCs and IHCs are lost and the sensory epithelium is replaced by flat cells. (D) A scanning electron microscopic image of cochlear FE. Scale bars represent $20 \mu \mathrm{m}$ (B, C and D).

\section{A}

Normal vestibular sensory epithelium

Flat epithelium
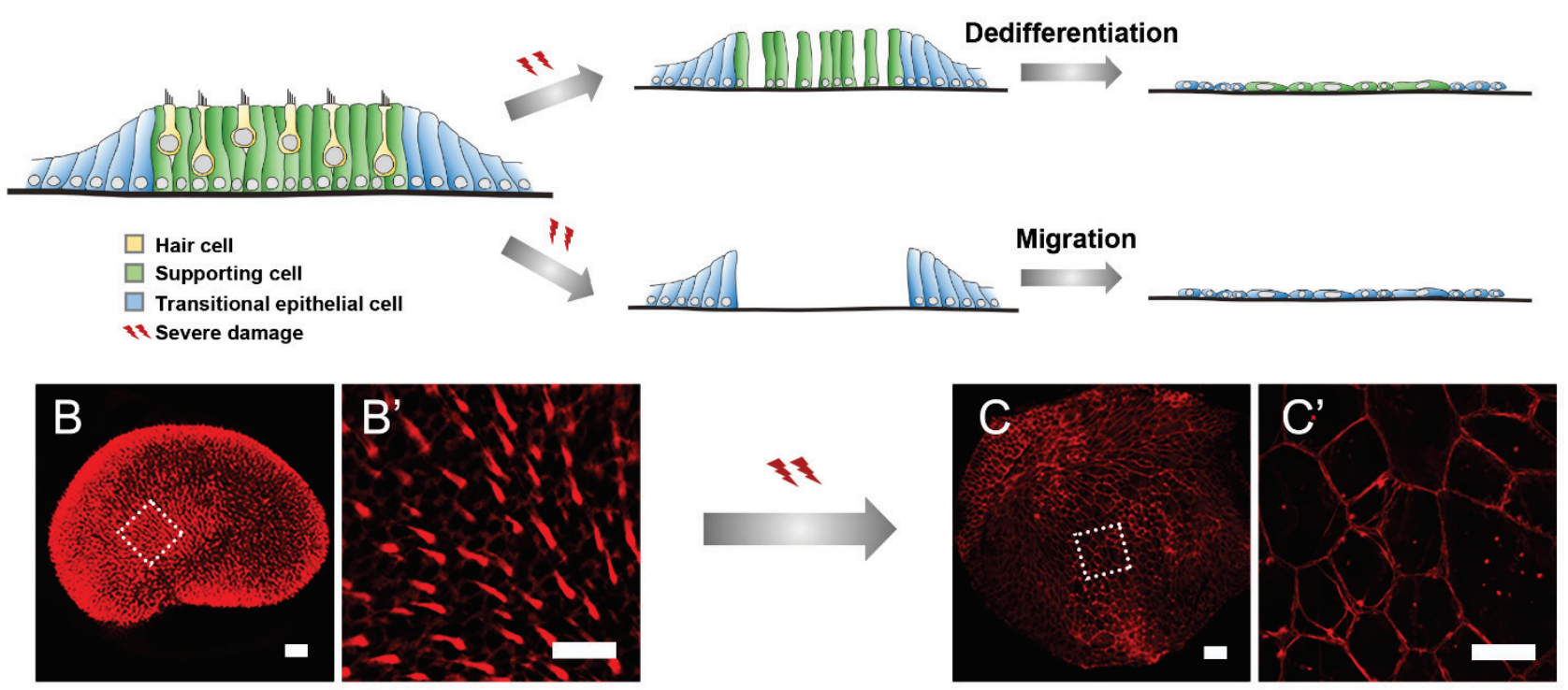

Fig. 2. Postulated mechanisms of formation of vestibular flat epithelium (FE) in mammals. (A) Schematic figures of vestibular FE formation. (B-B') Confocal images showing normal vestibular sensory epithelium stained by phalloidin. (B') High-magnification image of the dotted square in (B) shows stereocilia structure. (C-C') Confocal images showing vestibular FE stained by phalloidin. ( $\left.\mathbf{C}^{\prime}\right)$ High-magnification image of the dotted square in (C) shows the contour of flat cells. Scale bars represent $50 \mu \mathrm{m}(\mathrm{B}$ and $\mathrm{C})$ or $20 \mu \mathrm{m}\left(B^{\prime}\right.$ and $\left.C^{\prime}\right)$.

Gene therapy

Gene therapy has been used in animals with inner ear diseases for more than 20 years (Guo et al.
2018, Raphael et al. 1996, Wang et al. 2014). Atoh1 is an important regulator of the development and differentiation of HCs (Li et al. 2016, Richardson and 
Atkinson 2015, Zhong et al. 2019). Overexpression of Atoh1 promotes the differentiation of SCs into HCs in the developing inner ear and damaged inner ear of mouse (Gao et al. 2016, Hicks et al. 2020, Liu et al. 2012, Sayyid et al. 2019). Nevertheless, overexpression of Atohl in cochlear FE fails to induce HC regeneration (Izumikawa et al. 2008). In vestibular FE, Atoh1 overexpression plus SAHA induces vestibular FE to express myosin VIIa; however, these cells were morphologically different from mature $\mathrm{HCs}$ ( $\mathrm{He}$ et al. 2020). These studies indicate that flat cells do not possess properties of the original SCs, which poses a great challenge for gene therapy in FE of the inner ear. As flat epithelial cells may have regressed to an early stage of differentiation, regeneration of $\mathrm{FE}$ is unlikely to be induced by exclusively manipulating Atohl (Izumikawa et al. 2008, Yamoah et al. 2020). A variety of combinatorial genetic approaches have been applied to regeneration of HCs in the inner ear (Srivastava and DeWitt 2016). HC differentiation requires an essential set of genes, including Atohl, Pou4f3, Gfil, and miRNA-183 (Jahan et al. 2015, Pauley et al. 2008, Yamoah et al. 2020), and co-expression of Atohl with other factors, such as $\beta$-catenin, GATA, and Pou4f3, induces robust HC regeneration in the mouse cochlea (Kuo et al. 2015, Ni et al. 2016, Walters et al. 2017). Transcriptome analyses have identified multiple genes that function during inner-ear development and regeneration, suggesting targets for FE gene therapy (Reh et al. 2016, Scheffer et al. 2015).

\section{Stem cell therapy}

Stem cells possess self-renewal ability and can be induced to differentiate into many types of cells (Cruciani et al. 2019, Travnickova and Bacakova 2018). Inner ear or other stem cells can be induced to differentiate into hair cell-like cells in vitro (LongworthMills et al. 2015, Savary et al. 2007, Warnecke et al. 2017). However, the following difficulties must be overcome to induce differentiation of stem cells to HCs in vivo: 1) exogenous stem cells are unable to adapt to the high potassium ion concentration in endolymph, which causes their death (Lee and Park 2018); 2) tight junctions at the apical end of FE hamper colonization by stem cells; and 3) differentiation into functional $\mathrm{HCs}$ may require a series of complex regulatory processes. HeLa cells and human embryonic stem cells survive in the normal auditory epithelium and FE for at least 7 days if the potassium concentration is reduced (Lee et al. 2017, Park et al. 2014). Further research is needed to prolong the survival and induce stem cell differentiation.

\section{Conclusions}

FE is a pathological change that occurs after severe damage to the sensory epithelium of the inner ear. $\mathrm{FE}$ is present in human temporal bone specimens and mouse inner ear samples with profound hearing loss and/or vestibular disorders induced by ototoxic drugs, noise, and genetic factors. FE has different characteristics than inner ear sensory cells and shows innervation degeneration of variable degrees. Cochlear FE is unable to regenerate in mature mice, but vestibular FE may have limited regeneration ability. The expression levels of molecular markers change during FE formation, which may provide insight into the characteristics and formation of FE. Further studies should focus on means by which gene regulation and/or stem cell colonization can promote FE regeneration and maintain innervation.

\section{Conflict of Interest}

There is no conflict of interest.

\section{Acknowledgements}

This work was supported by the National Natural Science Foundation of China (81771016, 81830030, and 81900929) and the Beijing Hospitals Authority Youth Program (grant number QML20180101).

\section{References}

BOMMAKANTI K, IYER JS, STANKOVIC KM: Cochlear histopathology in human genetic hearing loss: state of the science and future prospects. Hear Res 382: 107785, 2019. https://doi.org/10.1016/j.heares.2019.107785

BUDENZ CL, WONG HT, SWIDERSKI DL, SHIBATA SB, PFINGST BE, RAPHAEL Y: Differential effects of AAV.BDNF and AAV.Ntf3 in the deafened adult guinea pig ear. Sci Rep 5: 8619, 2015. https://doi.org/10.1038/srep08619

CHEN Z, SHAO Y, LI X: The roles of signaling pathways in epithelial-to-mesenchymal transition of PVR. Mol Vis 21: 706-710, 2015. 
COCO A, EPP S, FALLON J, XU J, MILLARD R, SHEPHERD R: Does cochlear implantation and electrical stimulation affect residual hair cells and spiral ganglion neurons? Hear Res 225: 60-70, 2007. https://doi.org/10.1016/j.heares.2006.12.004

COTANCHE D, MESSANA E, OFSIE M: Migration of hyaline cells into the chick basilar papilla during severe noise damage. Hear Res 91: 148-159, 1995. https://doi.org/10.1016/0378-5955(95)00185-9

CRUCIANI S, GARRONI G, VENTURA C, DANANI A, NECAS A, MAIOLI M: Stem cells and physical energies: can we really drive stem cell fate? Physiol Res 68 (Suppl 4): S375-S384, 2019. https://doi.org/10.33549/physiolres.934388

DABDOUB A, PULIGILlA C, JONES JM, FRITZSCH B, CHEAH KS, PEVNY LH, KELLEY MW: Sox2 signaling in prosensory domain specification and subsequent hair cell differentiation in the developing cochlea. Proc Natl Acad Sci U S A 105: 18396-18401, 2008. https://doi.org/10.1073/pnas.0808175105

FRITZSCH B, DILLARD M, LAVADO A, HARVEY NL, JAHAN I: Canal cristae growth and fiber extension to the outer hair cells of the mouse ear require Prox1 activity. PLoS One 5: e9377, 2010. https://doi.org/10.1371/journal.pone.0009377

FRITZSCH B, MATEI V, NICHOLS D, BERMINGHAM N, JONES K, BEISEL K, WANG V: Atoh1 null mice show directed afferent fiber growth to undifferentiated ear sensory epithelia followed by incomplete fiber retention. Dev Dyn 233: 570-583, 2005. https://doi.org/10.1002/dvdy.20370

FUKUI H, RAPHAEL Y: Gene therapy for the inner ear. Hear Res 297: 99-105, 2013. https://doi.org:10.1016/j.heares.2012.11.017

GAO Z, KELLY MC, YU D, WU H, LIN X, CHI FL, CHEN P: Spatial and age-dependent hair cell generation in the postnatal mammalian utricle. Mol Neurobiol 53: 1601-1612, 2016. https://doi.org/10.1007/s12035-015-9119-0

GIROD D, DUCKERT L, RUBEL E: Possible precursors of regenerated hair cells in the avian cochlea following acoustic trauma. Hear Res 42: 175-194, 1989. https://doi.org/10.1016/0378-5955(89)90143-3

GUO JY, HE L, QU TF, LIU YY, LIU K, WANG GP, GONG SS: Canalostomy as a surgical approach to local drug delivery into the inner ears of adult and neonatal mice. J Vis Exp 135: e57351, 2018. https://doi.org/10.3791/57351

HE L, GUO JY, QU TF, WEI W, LIU K, PENG Z, WANG GP, GONG SS: Cellular origin and response of flat epithelium in the vestibular end organs of mice to Atoh1 overexpression. Hear Res 391: 107953, 2020. https://doi.org/10.1016/i.heares.2020.107953

HICKS KL, WISNER SR, COX BC, STONE JS: Atoh1 is required in supporting cells for regeneration of vestibular hair cells in adult mice. Hear Res 385: 107838, 2020. https://doi.org/10.1016/j.heares.2019.107838

HU Z, CORWIN JT: Inner ear hair cells produced in vitro by a mesenchymal-to-epithelial transition. Proc Natl Acad Sci U S A 104: 16675-16680, 2007. https://doi.org/10.1073/pnas.0704576104

ISAKOV N: Protein kinase C (PKC) isoforms in cancer, tumor promotion and tumor suppression. Semin Cancer Biol 48: 36-52, 2018. https://doi.org/10.1016/j.semcancer.2017.04.012

IZUMIKAWA M, BATTS S, MIYAZAWA T, SWIDERSKI D, RAPHAEL Y: Response of the flat cochlear epithelium to forced expression of Atoh1. Hear Res 240: 52-56, 2008. https://doi.org/10.1016/j.heares.2008.02.007

JAGGER DJ, FORGE A: Connexins and gap junctions in the inner ear - it's not just about K+ recycling. Cell Tissue Res 360: 633-644, 2014. https://doi.org/10.1007/s00441-014-2029-z

JAHAN I, PAN N, FRITZSCH B: Opportunities and limits of the one gene approach: the ability of Atoh1 to differentiate and maintain hair cells depends on the molecular context. Front Cell Neurosci 9: $26,2015$. https://doi.org/10.3389/fncel.2015.00026

JAHAN I, ELLIOTT KL, FRITZSCH B: Understanding molecular evolution and development of the organ of Corti can provide clues for hearing restoration. Integr Comp Biol 58: 351-365, 2018. https://doi.org/10.1093/icb/icy019

JIANG M, KARASAWA T, STEYGER PS: Aminoglycoside-induced cochleotoxicity: a review. Front Cell Neurosci 11: 308, 2017. https://doi.org/10.3389/fncel.2017.00308

JOHNEN N, FRANCART M, THELEN N, CLOES M, THIRY M: Evidence for a partial epithelial-mesenchymal transition in postnatal stages of rat auditory organ morphogenesis. Histochem Cell Biol 138: 477-488, 2012. https://doi.org/10.1007/s00418-012-0969-5 
JUN A, MCGUIRT W, HINOJOSA R, GREEN G, FISCHEL-GHODSIAN N, SMITH R: Temporal bone histopathology in connexin 26-related hearing loss. Laryngoscope 110: 269-275, 2000. https://doi.org/10.1097/00005537-200002010-00016

KALCHEIM C: Epithelial-mesenchymal transitions during neural crest and somite development. J Clin Med 5: E1, 2015. https://doi.org/10.3390/jcm5010001

KIM YH, RAPHAEL Y: Cell division and maintenance of epithelial integrity in the deafened auditory epithelium. Cell Cycle 6: 612-619, 2007. https://doi.org/10.4161/cc.6.5.3929

KOBAYASHI Y, NAKAMURA H, FUNAHASHI J: Epithelial-mesenchymal transition as a possible mechanism of semicircular canal morphogenesis in chick inner ear. Tohoku J Exp Med 215: 207-217, 2008. https://doi.org/10.1620/tjem.215.207

KUJAWA SG, LIBERMAN MC: Adding insult to injury: cochlear nerve degeneration after "temporary" noise-induced hearing loss. J Neurosci 29: 14077-14085, 2009. https://doi.org/10.1523/jneurosci.2845-09.2009

KUO BR, BALDWIN EM, LAYMAN WS, TAKETO MM, ZUO J: In vivo cochlear hair cell generation and survival by coactivation of beta-catenin and Atoh1. J Neurosci 35: 10786-10798, 2015. https://doi.org/10.1523/jneurosci.0967-15.2015

KUSUNOKI T, CUREOGLU S, SCHACHERN PA, BABA K, KARIYA S, PAPARELLA MM: Age-related histopathologic changes in the human cochlea: a temporal bone study. Otolaryngol Head Neck Surg 131: 897-903, 2004a. https://doi.org/10.1016/j.otohns.2004.05.022

KUSUNOKI T, CUREOGLU S, SCHACHERN P, SAMPAIO A, FUKUSHIMA H, OKTAY M, PAPARELLA M: Effects of aminoglycoside administration on cochlear elements in human temporal bones. Auris Nasus Larynx 31: 383-388, 2004b. https://doi.org/10.1016/s0385-8146(04)00147-6

KUZNETSOVA AV, KURINOV AM, ALEKSANDROVA MA: Cell models to study regulation of cell transformation in pathologies of retinal pigment epithelium. J Ophthalmol 2014: 801787, 2014. https://doi.org/10.1155/2014/801787

LADRECH S, EYBALIN M, PUEL JL, LENOIR M: Epithelial-mesenchymal transition, and collective and individual cell migration regulate epithelial changes in the amikacin-damaged organ of Corti. Histochem Cell Biol 148: 129-142, 2017. https://doi.org/10.1007/s00418-017-1548-6

LEE MY, PARK YH: Potential of gene and cell therapy for inner ear hair cells. Biomed Res Int 2018: 8137614, 2018. https://doi.org/10.1155/2018/8137614

LEE MY, HACKELBERG S, GREEN KL, LUNGHAMER KG, KURIOKA T, LOOMIS BR, SWIDERSKI DL, DUNCAN RK, RAPHAEL Y: Survival of human embryonic stem cells implanted in the guinea pig auditory epithelium. Sci Rep 7: 46058, 2017. https://doi.org/10.1038/srep46058

LEONOVA EV, RAPHAEL Y: Organization of cell junctions and cytoskeleton in the reticular lamina in normal and ototoxically damaged organ of Corti. Hear Res 113: 14-28, 1997. https://doi.org/10.1016/s0378-5955(97)00130-5

LI W, YOU D, CHEN Y, CHAI R, LI H: Regeneration of hair cells in the mammalian vestibular system. Front Med 10: 143-151, 2016. https://doi.org/10.1007/s11684-016-0451-1

LIU H, LI Y, CHEN L, ZHANG Q, PAN N, NICHOLS DH, ZHANG WJ, FRITZSCH B, HE DZ: Organ of Corti and Stria Vascularis: Is there an interdependence for survival? PLoS One 11: e0168953, 2016. https://doi.org/10.1371/journal.pone.0168953

LIU Z, DEARMAN JA, COX BC, WALTERS BJ, ZHANG L, AYRAULT O, ZINDY F, GAN L, ROUSSEL MF, ZUO J: Age-dependent in vivo conversion of mouse cochlear pillar and Deiters' cells to immature hair cells by Atoh1 ectopic expression. J Neurosci 32: 6600-6610, 2012. https://doi.org/10.1523/jneurosci.0818-12.2012

LONGWORTH-MILLS E, KOEHLER KR, HASHINO E: Generating inner ear organoids from mouse embryonic stem cells. Methods Mol Biol 1341: 391-406, 2015. https://doi.org/10.1007/7651_2015_215

MAKARY CA, SHIN J, KUJAWA SG, LIBERMAN MC, MERCHANT SN: Age-related primary cochlear neuronal degeneration in human temporal bones. J Assoc Res Otolaryngol 12: 711-717, 2011. https://doi.org/10.1007/s10162-011-0283-2

MCCALL AA, ISHIYAMA GP, LOPEZ IA, BHUTA S, VETTER S, ISHIYAMA A: Histopathological and ultrastructural analysis of vestibular endorgans in Meniere's disease reveals basement membrane pathology. BMC Ear Nose Throat Disord 9: 4, 2009. https://doi.org/10.1186/1472-6815-9-4 
MEYERS JR, CORWIN JT: Shape change controls supporting cell proliferation in lesioned mammalian balance epithelium. J Neurosci 27: 4313-4325, 2007. https://doi.org/10.1523/jneurosci.5023-06.2007

NADOL JB, EDDINGTON D: Histopathology of the inner ear relevant to cochlear implantation. Adv Otorhinolaryngol 64: 31-49, 2006. https://doi.org/10.1159/000094643

NADOL JB, HANDZEL O, AMR S: Histopathology of the human inner ear in a patient with sensorineural hearing loss caused by a variant in DFNA5. Otol Neurotol 36: 1616-1621, 2015. https://doi.org/10.1097/mao.0000000000000888

NADOL JB, YOUNG Y, GLYNN R: Survival of spiral ganglion cells in profound sensorineural hearing loss: implications for cochlear implantation. Ann Otol Rhinol Laryngol 98: 411-416, 1989. https://doi.org/10.1177/000348948909800602

NAPLES JG, RUCKENSTEIN MJ: Cochlear implant. Otolaryngol Clin North Am 53: 87-102, 2020. https://doi.org/10.1016/j.otc.2019.09.004

NI W, LIN C, GUO L, WU J, CHEN Y, CHAI R, LI W, LI H: Extensive supporting cell proliferation and mitotic hair cell generation by in vivo genetic reprogramming in the neonatal mouse cochlea. J Neurosci 36: 8734-8745, 2016. https://doi.org/10.1523/jneurosci.0060-16.2016

NIETO MA, HUANG RY, JACKSON RA, THIERY JP: EMT: $2016 . \quad$ Cell 166: 21-45, 2016. https://doi.org/10.1016/j.cell.2016.06.028

PAN N, JAHAN I, KERSIGO J, DUNCAN JS, KOPECKY B, FRITZSCH B: A novel Atoh1 "self-terminating" mouse model reveals the necessity of proper Atoh1 level and duration for hair cell differentiation and viability. PLoS One 7: e30358, 2012. https://doi.org/10.1371/journal.pone.0030358

PAN N, JAHAN I, KERSIGO J, KOPECKY B, SANTI P, JOHNSON S, SCHMITZ H, FRITZSCH B: Conditional deletion of Atoh1 using Pax2-Cre results in viable mice without differentiated cochlear hair cells that have lost most of the organ of Corti. Hear Res 275: 66-80, 2011. https://doi.org/10.1016/j.heares.2010.12.002

PARK YH, WILSON KF, UEDA Y, TUNG WONG H, BEYER LA, SWIDERSKI DL, DOLAN DF, RAPHAEL Y: Conditioning the cochlea to facilitate survival and integration of exogenous cells into the auditory epithelium. Mol Ther 22: 873-880, 2014. https://doi.org/10.1038/mt.2013.292

PAULEY S, KOPECKY B, BEISEL K, SOUKUP G, FRITZSCH B: Stem cells and molecular strategies to restore hearing. Panminerva Med 50: 41-53, 2008.

PAWLOWSKI KS, KIKKAWA YS, WRIGHT CG, ALAGRAMAM KN: Progression of inner ear pathology in Ames Waltzer mice and the role of protocadherin 15 in hair cell development. J Assoc Res Otolaryngol 7: 83-94, 2006. https://doi.org/10.1007/s10162-005-0024-5

PEREZ FA, CAVUSCENS S, RANIERI M, VAN DE BERG R, STOKROOS R, KINGMA H, GUYOT J-P, GUINAND $\mathrm{N}$ : The vestibular implant: A probe in orbit around the human balance system. J Vestib Res 27: 51-61, 2017. https://doi.org/10.3233/ves-170604

RAPHAEL Y, KIM YH, OSUMI Y, IZUMIKAWA M: Non-sensory cells in the deafened organ of Corti: approaches for repair. Int J Dev Biol 51: 649-654, 2007. https://doi.org/10.1387/ijdb.072370yr

RAPHAEL Y, FRISANCHO JC, ROESSLER BR: Adenoviral-mediated gene transfer into guinea pig cochlear cells in vivo. Neurosci Lett 207: 137-141, 1996. https://doi.org/10.1016/0304-3940(96)12499-x

HINOJOSA R, NELSON EG, LERNER SA, REDLEAF MI, SCHRAMM DR: Aminoglycoside ototoxicity: a human temporal bone study. Laryngoscope 111: 1797-1805, 2001. https://doi.org/10.1097/00005537-200110000-00025

REH T, MAASS J, GU R, CAI T, WAN Y, CANTELLANO S, ASPRER J, ZHANG H, JEN H, EDLUND R, LIU Z, GROVES A: Transcriptomic analysis of mouse cochlear supporting cell maturation reveals large-scale changes in Notch responsiveness prior to the onset of hearing. PLoS One 11: e0167286, 2016. https://doi.org/10.1371/journal.pone.0167286

RICHARDSON R, ATKINSON P: Atoh1 gene therapy in the cochlea for hair cell regeneration. Expert Opin Biol Ther 15: 417-430, 2015. https://doi.org/10.1517/14712598.2015.1009889

ROBERTO M, ZITO F: Scar formation following impulse noise-induced mechanical damage to the organ of Corti. J Laryngol Otol 102: 2-9, 1988. https://doi.org/10.1017/s0022215100103822 
SAVARY E, HUGNOT JP, CHASSIGNEUX Y, TRAVO C, DUPERRAY C, VAN DE WATER T, ZINE A: Distinct population of hair cell progenitors can be isolated from the postnatal mouse cochlea using side population analysis. Stem Cells 25: 332-339, 2007. https://doi.org/10.1634/stemcells.2006-0303

SAYYID ZN, WANG T, CHEN L, JONES SM, CHENG AG: Atoh1 directs regeneration and functional recovery of the mature mouse vestibular system. Cell Rep 28: 312-324, 2019. https://doi.org/10.1016/j.celrep.2019.06.028

SCHEFFER DI, SHEN J, COREY DP, CHEN ZY: Gene expression by mouse inner ear hair cells during development. J Neurosci 35: 6366-6380, 2015. https://doi.org/10.1523/jneurosci.5126-14.2015

SHIBATA SB, RAPHAEL Y: Future approaches for inner ear protection and repair. J Commun Disord 43: 295-310, 2010. https://doi.org/10.1016/j.jcomdis.2010.04.001

SHIBATA SB, BUDENZ CL, BOWLING SA, PFINGST BE, RAPHAEL Y: Nerve maintenance and regeneration in the damaged cochlea. Hear Res 281: 56-64, 2011. https://doi.org/10.1016/j.heares.2011.04.019

SHIBATA SB, CORTEZ SR, BEYER LA, WILER JA, DI POLO A, PFINGST BE, RAPHAEL Y: Transgenic BDNF induces nerve fiber regrowth into the auditory epithelium in deaf cochleae. Exp Neurol 223: 464-472, 2010. https://doi.org/10.1016/j.expneurol.2010.01.011

SIMONNEAU L, GALLEGO M, PUJOL R: Comparative expression patterns of T-, N-, E-cadherins, beta-catenin, and polysialic acid neural cell adhesion molecule in rat cochlea during development: implications for the nature of Kolliker's organ. J Comp Neurol 459: 113-126, 2003. https://doi.org/10.1002/cne.10604

SMITTKAMP S, PARK D, GIROD D, DURHAM D: Effects of age and cochlear damage on the metabolic activity of the avian cochlear nucleus. Hear Res 175: 101-111, 2003. https://doi.org/10.1016/s0378-5955(02)00714-1

SRIVASTAVA D, DEWITT N: In vivo cellular reprogramming: The next generation. Cell 166: 1386-1396, 2016. https://doi.org/10.1016/j.cell.2016.08.055

SUGAWARA M, CORFAS G, LIBERMAN MC: Influence of supporting cells on neuronal degeneration after hair cell loss. J Assoc Res Otolaryngol 6: 136-147, 2005. https://doi.org/10.1007/s10162-004-5050-1

SUN Y, TANG W, CHANG Q, WANG Y, KONG W, LIN X: Connexin30 null and conditional connexin26 null mice display distinct pattern and time course of cellular degeneration in the cochlea. J Comp Neurol 516: 569-579, 2009. https://doi.org/10.1002/cne.22117

TAKADA Y, BEYER LA, SWIDERSKI DL, O'NEAL AL, PRIESKORN DM, SHIVATZKI S, AVRAHAM KB, RAPHAEL Y: Connexin 26 null mice exhibit spiral ganglion degeneration that can be blocked by BDNF gene therapy. Hear Res 309: 124-135, 2014. https://doi.org/10.1016/j.heares.2013.11.009

TAMIYA S, LIU L, KAPLAN HJ: Epithelial-mesenchymal transition and proliferation of retinal pigment epithelial cells initiated upon loss of cell-cell contact. Invest Ophthalmol Vis Sci 51: 2755-2763, 2010. https://doi.org/10.1167/iovs.09-4725

TAYLOR RR, JAGGER DJ, FORGE A: Defining the cellular environment in the organ of Corti following extensive hair cell loss: a basis for future sensory cell replacement in the Cochlea. PLoS One 7: e30577, 2012. https://doi.org/10.1371/journal.pone.0030577

TEUFERT K, LINTHICUM FJ, CONNELL S: The effect of organ of Corti loss on ganglion cell survival in humans. Otol Neurotol 27: 1146-1151, 2006. https://doi.org/10.1097/01.mao.0000232006.16363.44

TRAVNICKOVA M, BACAKOVA L: Application of adult mesenchymal stem cells in bone and vascular tissue engineering. Physiol Res 67: 831-850, 2018. https://doi.org/10.33549/physiolres.933820

WAGENAAR M, SCHUKNECHT H, NADOL J, BENRAAD-VAN RENS M, PIEKE-DAHL S, KIMBERLING W, CREMERS C: Histopathologic features of the temporal bone in Usher syndrome type I. Arch Otolaryngol Head Neck Surg 126: 1018-1023, 2000. https://doi.org/10.1001/archotol.126.8.1018

WALTERS BJ, COAK E, DEARMAN J, BAILEY G, YAMASHITA T, KUO B, ZUO J: In vivo interplay between p27(Kip1), GATA3, ATOH1, and POU4F3 converts non-sensory cells to hair cells in adult mice. Cell Rep 19: 307-320, 2017. https://doi.org/10.1016/j.celrep.2017.03.044

WANG GP, GUO JY, PENG Z, LIU YY, XIE J, GONG SS: Adeno-associated virus-mediated gene transfer targeting normal and traumatized mouse utricle. Gene Ther 21: 958-966, 2014. https://doi.org/10.1038/gt.2014.73

WANG GP, CHATTERJEE I, BATTS SA, WONG HT, GONG TW, GONG SS, RAPHAEL Y: Notch signaling and Atoh1 expression during hair cell regeneration in the mouse utricle. Hear Res 267: 61-70, 2010. https://doi.org/10.1016/j.heares.2010.03.085 
WANG GP, BASU I, BEYER LA, WONG HT, SWIDERSKI DL, GONG SS, RAPHAEL Y: Severe streptomycin ototoxicity in the mouse utricle leads to a flat epithelium but the peripheral neural degeneration is delayed. Hear Res 355: 33-41, 2017. https://doi.org/10.1016/j.heares.2017.09.004

WARNECKE A, MELLOTT AJ, RÖMER A, LENARZ T, STAECKER H: Advances in translational inner ear stem cell research. Hear Res 353: 76-86, 2017. https://doi.org/10.1016/j.heares.2017.05.011

WILLOTT JF, BROSS LS, MCFADDEN SL: Morphology of the cochlear nucleus in CBA/J mice with chronic, severe sensorineural cochlear pathology induced during adulthood. Hear Res 74: 1-21, 1994. https://doi.org/10.1016/0378-5955(94)90171-6

WISE AK, HUME CR, FLYNN BO, JEELALL YS, SUHR CL, SGRO BE, O'LEARY SJ, SHEPHERD RK, RICHARDSON RT: Effects of localized neurotrophin gene expression on spiral ganglion neuron resprouting in the deafened cochlea. Mol Ther 18: 1111-1122, 2010. https://doi.org/10.1038/mt.2010.28

YAMASOBA T, KONDO K: Supporting cell proliferation after hair cell injury in mature guinea pig cochlea in vivo. Cell Tissue Res 325: 23-31, 2006. https://doi.org/10.1007/s00441-006-0157-9

YAMOAH EN, LI M, SHAH A, ELLIOTT KL, CHEAH K, XU PX, PHILLIPS S, YOUNG SM JR, EBERL DF, FRITZSCH B: Using Sox2 to alleviate the hallmarks of age-related hearing loss. Ageing Res Rev 59: 101042, 2020. https://doi.org/10.1016/j.arr.2020.101042

YANG SM, CHEN W, GUO WW, JIA S, SUN JH, LIU HZ, YOUNG WY, HE DZZ: Regeneration of stereocilia of hair cells by forced Atoh1 expression in the adult mammalian cochlea. PLoS One 7: e46355, 2012. https://doi.org/10.1371/journal.pone.0046355

ZHANG L, HU Z: Sensory epithelial cells acquire features of prosensory cells via epithelial to mesenchymal transition. Stem Cells Dev 21: 1812-1821, 2012. https://doi.org/10.1089/scd.2011.0443

ZHONG C, FU Y, PAN W, YU J, WANG J: Atoh1 and other related key regulators in the development of auditory sensory epithelium in the mammalian inner ear: function and interplay. Dev Biol 446: 133-141, 2019. https://doi.org/10.1016/j.ydbio.2018.12.025

ZILBERSTEIN Y, LIBERMAN MC, CORFAS G: Inner hair cells are not required for survival of spiral ganglion neurons in the adult cochlea. J Neurosci 32: 405-410, 2012. https://doi.org/10.1523/jneurosci.4678-11.2012 